\title{
KOMPOSISI ASAM AMINO SEBAGAI PENANDA KIMIA DARI AKUMULASI LOGAM BERAT DI BIOTA KERANG HIJAU (Perna viridis)
}

\section{Amino Acids Composition as a Chemical Marker for Heavy Metals Accumulation in Green Mussle Perna viridis}

\author{
Hedi indra Januar*, Irma Hermana, dan Dwiyitno \\ Balai Besar Riset Pengolahan Produk dan Bioteknologi Kelautan dan Perikanan, \\ JI. KS Tubun, Petamburan VI, Jakarta Pusat, Indonesia \\ ${ }^{*}$ Korespondensi Penulis: idjanuar@kkp.go.id
}

Diterima: 1 April 2020; Direvisi: 2 Juli 2020; Disetujui: 6 Juli 2020

\begin{abstract}
ABSTRAK
Logam berat merupakan variabel penting dalam penelaahan keamanan produk kekerangan. Namun, kuantifikasinya membutuhkan tingkat kesiapan analis dan peralatan laboratorium yang modern. Hal ini mendorong usulan berbagai metode penapisan High-throughput Screening seperti komposisi asam amino, sebagai penanda kimia pada penapisan tahap awal dari kontaminasi logam berat di biota kekerangan. Penelitian ini bertujuan untuk mengetahui fisibilitas komposisi asam amino yang terkandung pada produk kekerangan, sebagai penanda kimia akumulasi logam berat. Biota kerang bernilai ekonomis, yaitu kerang hijau (Perna viridis), dipilih sebagai target yang diambil dari tiga lokasi budidaya di Perairan Cirebon (sisi utara, perairan kota, dan sisi timur). Kadar logam berat ( $\mathrm{Cr}, \mathrm{Co}, \mathrm{Cu}, \mathrm{As}, \mathrm{Cd}, \mathrm{Hg}$, dan $\mathrm{Pb}$ ) dianalisis mempergunakan ICPMS (Inductively Coupled Plasma-Mass Spectrometry), sementara kandungan asam amino ditelaah dengan kromatografi gas yang dilengkapi Flame Ionization Detector (FID). Hasil pengujian memperlihatkan bahwa kadar tertinggi dari tiap logam berat pada $P$. viridis adalah $0,25 \mathrm{mg} / \mathrm{kg}$ (Cr); 0,2 mg/kg (Co); 2,1 mg/kg (Cu); 1,5 mg/kg (As); 0,25 mg/kg (Cd); 0,25 mg/kg (Hg); dan 0,1 $\mathrm{mg} / \mathrm{kg}(\mathrm{Pb})$. Nilai ini masih memenuhi persyaratan baku mutu, kecuali kadar arsen. Pengujian statistika korespondensi menunjukkan bahwa kadar asam amino kerang hijau dapat mengalami pergeseran komposisi yang tergantung pada tipe, variasi, dan kuantifikasi akumulasi logam beratnya. Oleh karena itu, tidak ada satupun jenis asam amino tertentu yang dapat dijadikan sebagai penanda kimia umum dari akumulasi berbagai jenis logam berat. Penelitian lebih lanjut dapat dilakukan untuk menemukan faktor pembanding menggunakan senyawa tertentu yang dapat melengkapi rasio komposisi asam amino sebagai penanda kimia dari akumulasi logam berat pada biota kekerangan.
\end{abstract}

KATA KUNCI : asam amino, kerang hijau (Perna viridis), logam berat, kekerangan

\begin{abstract}
Heavy metals are important factor in the food safety analysis of marine mussels. However, heavy metal quantification requires factors an adequate analyst and modern laboratory equipment. Therefore, various high throughput screening methods have been proposed, such as the composition of amino acids as a marker in a preliminary screening of heavy metal contamination in marine mussels. This study aimed to determine the feasibility of amino acids composition in marine mussels as a chemical marker of heavy metal accumulation. The commercial marine

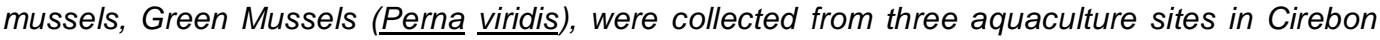
Waters (north side, in front of the city, and east side). Heavy metals content (Cr, Co, Cu, $\mathrm{As}, \mathrm{Cd}, \mathrm{Hg}$, and $\mathrm{Pb}$ ) was analyzed by ICP-MS (Inductively Coupled Plasma-Mass Spectrometry) technique while the amino acids content was analyzed using gas chromatography with Flame lonization Detector (FID). Results of this study showed that the maximum value of each heavy metal in $\underline{P}$. viridis were $0.25 \mathrm{mg} / \mathrm{kg}(\mathrm{Cr}) ; 0.2 \mathrm{mg} / \mathrm{kg}$ (Co); $2.1 \mathrm{mg} / \mathrm{kg}(\mathrm{Cu}) ; 1.5 \mathrm{mg} / \mathrm{kg}$ (As); $0.25 \mathrm{mg} / \mathrm{kg}(\mathrm{Cd})$; $0.25 \mathrm{mg} / \mathrm{kg}(\mathrm{Hg}) ;$ and $0.1 \mathrm{mg} / \mathrm{kg}(\mathrm{Pb})$. Except for arsenic, these values were below the allowable threshold level. Correspondence analysis showed that the composition of amino acids in the green mussels was shifted, according to the type, variation, and quantification of the accumulated heavy metals. Therefore, none of the amino acids can be used as a general chemical marker for various types of heavy metals. Further research can be done to identify a particular comparative compound that can complement the ratio of amino acids composition as biomarkers for heavy metals accumulation in marine mussels.
\end{abstract}

KEYWORDS: amino acids, green mussel (Perna viridis), heavy metals, marine mussels 


\section{PENDAHULUAN}

Logam berat merupakan kontaminan kimiawi berbahaya yang sering mencemari wilayah pesisir laut. Limpasan antropogenik yang tidak diolah dengan baik, seperti dari perindustrian, pertanian, dan lainnya, akan terbawa sampai ke lingkungan pesisir laut (Sindern et al., 2016). Akumulasi logam telah terdeteksi melebihi ambang batas yang ditetapkan oleh Keputusan Menteri Lingkungan Hidup No. 51/ 2004, di beberapa wilayah pesisir yang mendapat limpasan dari area padat penduduk, seperti Muara Cilincing dan Kalibaru Jakarta (Barokah, Dwiyitno, \& Nugroho, 2019). Keberadaan bahan berbahaya ini dapat menurunkan tingkat keamanan pangan produk perikanan, terutama biota bentos seperti kekerangan. Akumulasi logam berat pada kerang hijau (Perna viridis), seperti $\mathrm{Fe}, \mathrm{Cd}, \mathrm{Hg}$, dan $\mathrm{Pb}$, telah dilaporkan juga dari berbagai wilayah pesisir Indonesia, seperti di Perairan Trimulyo - Semarang, Teluk Jakarta, Perairan Wonosari - Demak, dan Perairan Cirebon (Falah, Purnomo, \& Suryanto, 2018; Jalius, Setiyanto, Sumantadinata, Riani, \& Ernawati, 2016; Murraya, Taufiq, \& Supriyantini, 2018; Nurhayati \& Putri, 2019). Hal ini menyebabkan pemantauan kadar logam berat secara berkala di kekerangan merupakan penelaahan yang penting untuk menjaga keamanannya sebagai produk pangan.

Penelaahan kadar logam berat merupakan analisis yang kompleks. Setiap logam berat memiliki sifat kelarutan yang berbeda, seperti krom $(\mathrm{Cr})$ adalah logam hard Lewis acid, timbal $(\mathrm{Pb})$, besi $(\mathrm{Fe})$, dan kobalt (Co) merupakan logam intermediate Lewis acid, sementara merkuri $(\mathrm{Hg})$ termasuk logam soft Lewis acid (Çiçek \& Calýsýr, 2016; Wu et al., 2019). Hal ini berdampak pada perbedaan kelarutannya, sehingga diperlukan beberapa set preparasi pada satu sampel yang sama, untuk target logam berat yang berbeda. Selain itu, ketelitian tinggi dan kontrol kualitas alat yang baik juga diperlukan. Logam berat soft Lewis acid, seperti merkuri, dapat menyebabkan "memory effects" (terendapkannya di jalur sepanjang injektor sampel ke detektor) di instrumentasi pengujian, contohnya pada AAS (Atomic Absroption Spectrometer) dan ICP-MS (Induced Coupled Plasma-Mass Spectrometer). Kontaminasi silang antar sampel terjadi jika tidak dilakukan intervensi dan perawatan yang tepat (Barros, Pinheiro, Amaral, Lorençatto, \& Nóbrega, 2018; Kim, Lim, Hwang, \& Yim, 2016).

Oleh karena itu, beberapa penelitian telah dilakukan untuk merancang metode preparasi dan pengujian yang dapat mencakup semua jenis logam, serta mencari komposisi metabolik tertentu sebagai penanda kimia dalam penapisan tahap awal dari akumulasi logam berat. Pengujian proteomik atau metabolomik telah diusulkan sebagai HTS (high throughput screening) untuk memberi indikasi adanya akumulasi logam berbahaya (Aru, Sarais, Savorani, Engelsen, \& Marincola, 2016; Wu, Xu, Yu, \& Ji, 2017). Contohnya proteomik akumulasi logam arsen di kerang Mytilus galloprovincialis, kadmium dan tembaga di kerang hijau Perna viridis, serta kobalt di kerang Ruditapes philippinarum (Wu \& Wang, 2010; Yu, Ji, Zhao, \& Wu, 2016; Zhang et al., 2011). Hasilhasil riset tersebut menunjukkan adanya variasi beberapa jenis metabolisme, termasuk asam amino, pada paparan logam berat tertentu, sehingga prospektif sebagai metode HTS.

Pengujian yang telah dilakukan tersebut di atas baru dilakukan dalam laboratorium yang terkontrol, dengan satu atau dua jenis logam tertentu. Kondisi ini dapat jauh berbeda dengan karakteristik cemaran di perairan pesisir, yang terpapar berbagai jenis logam berat sehingga menghasilkan interaksi berbeda dengan faktor tunggal. Hal ini yang mendasari dilaksanakannya penelitian ini. Riset bertujuan untuk menelaah fisibilitas asam amino sebagai penanda kimia dari kondisi akumulasi logam berat kekerangan. Beberapa jenis logam berat (Cr, Co, Cu, As, Cd, Hg, dan $\mathrm{Pb}$ ) ditelaah korespondensinya dengan kadar asam amino, sehingga dapat dijadikan sebagai studi dasar untuk pengembangan HTS cemaran logam berat. Target penelitian adalah kerang hijau $P$. viridis yang merupakan biota ekonomis dari perairan pesisir. Lokasi pengambilan sampel dilakukan di Perairan Cirebon, sebagai salah satu sentra produksi perikanan kekerangan yang penting di Indonesia.

\section{BAHAN DAN METODE}

\section{Bahan}

Pengambilan bahan baku kerang hijau $P$. viridis dilakukan pada musim peralihan muson barat ke timur (Maret 2019) di tiga titik budidaya di Perairan Cirebon. Ketiga titik ini berada di sisi utara, perairan kotamadya, dan sisi timur. Posisi dari lokasi pengambilan sampel dicatat dengan perangkat GPS (Global Positioning System) Garmin GPSMAP 64s SEA, yang selanjutnya diplot ke peta Basecamp Garmin (Gambar 1). Sampel dari tiap lokasi diambil sebanyak 3 kantong berukuran $10 \mathrm{~kg}$, lalu disimpan dalam kotak pendingin yang suhunya dipertahankan pada kondisi sekitar $4^{\circ} \mathrm{C}$ (dengan penambahan es) untuk preservasi selama transportasi ke laboratorium di Balai Besar Riset Pengolahan Produk dan Bioteknologi Kelautan dan Perikanan-Jakarta. Selain itu, bahan kimia yang dipergunakan dalam penelitian adalah $\mathrm{HNO}_{3}$ (Superpure, Merck), standar logam berat ICP multi- 
element standard XIII (Merck Millipore), L-cystein (Merck), dan preparation-kitEZ-Faast (Phenomenex).

\section{Metode}

Daging kerang dari 100 individual sampel tiap kantong yang berbeda ( 3 kantong di tiap titik) diambil secara acak dan dikeringkan pada oven vaccum dengan suhu $60^{\circ} \mathrm{C}$ selama 3 hari. Kadar air dihitung dalam proses pengeringan, untuk konversi berat kering ke berat basah sampel. Sampel yang kering di homogenisasi membentuk komposit, lalu dibagi 3 (total sampel untuk tiap titik menjadi 9) untuk pengujian logam berat dan asam amino.

\section{Analisis logam berat}

Proses ekstraksi logam dilakukan dengan microwave digester (Berghof Speedwave 2), selaras dengan Siregar et al. (2016). Pengujian di instrumentasi ICP-MS, yang mempergunakan helium high matrix mode, dibagi atas dua set. Set pertama adalah untuk logam berat ${ }_{201} \mathrm{Hg}$, dengan $2 \% \mathrm{HNO}_{3}$ dan $0,2 \%$ L-cystein sebagai pelarut, pencuci antar sampel, dan blanko, selaras dengan metodologi yang dikemukakan oleh Li et al. (2006) untuk menghilangkan endapan logam $\mathrm{Hg}$ yang dapat terjadi di sepanjang jalur autosampler ke detektor alat. Sementara itu, set kedua adalah untuk pengujian logam berat ${ }_{52} \mathrm{Cr},{ }_{59} \mathrm{Co},{ }_{63} \mathrm{Cu},{ }_{75} \mathrm{As},{ }_{111} \mathrm{Cd}$, dan ${ }_{208} \mathrm{~Pb}$, yang mempergunakan $2 \% \mathrm{HNO}_{3}$ sebagai pelarut, pencuci antar sampel, serta blanko. Perhitungan konsentrasi logam dilakukan berdasarkan nilai regresi dari kurva larutan standar pada 6 konsentrasi (1-50 $\mathrm{ppb})$.

\section{Analisis asam amino}

Instrumentasi kromatografi gas (GC - Flame Ionization Detector Agilent 7890A) dipergunakan untuk kuantifikasi asam amino dalam sampel. Proses preparasi, injeksi sampel, spesifikasi kolom, dan gradien suhu alat, dilakukan sesuai dengan metodologi preparation-kit EZ-Faast Phenomenex yang dikemukakan Kechaou et al. (2009).

\section{Pengolahan Data}

Pengujian Kruskall-Wallis dan multivariat diskriminan dipergunakan untuk mengetahui perbedaan kadar logam berat dan asam amino sampel dari tiap lokasi. Normalitas data kadar logam berat dan asam amino pada uji multivariat diskriminan dilakukan mempergunakan transformasi log $(1+x)$ dan akar kuadrat. Selanjutnya, korespondensi antara multi-variabel logam berat dan asam amino ditelaah dengan multivariat korespondensi kanonikal. Keseluruhan uji statistik dilakukan dengan perangkat lunak Past Statistical Software V3.08 (Hammer, Harper, \& Ryan, 2001).

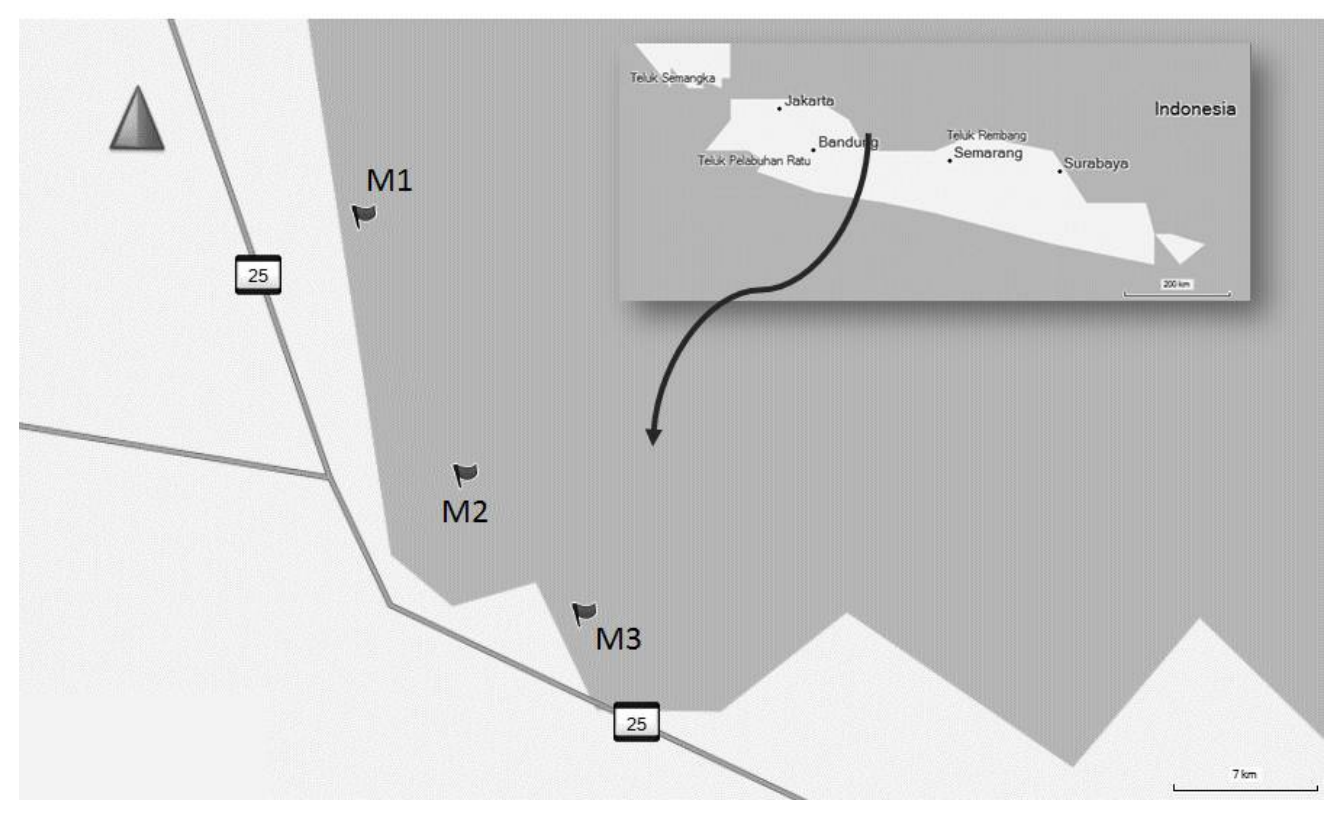

Gambar 1. Lokasi pengambilan sampel kerang hijau (P. viridis) di Perairan Cirebon, dengan titik M1 merupakan lokasi di sisi utara, M2 di perairan kotamadya, dan M3 di sisi timur

Figure 1. Sampling locations of green mussels ( $\underline{\underline{P}} \underline{\underline{v} \text { viridis }}$ ) in Cirebon Waters, M1 is the northern region, M2 is Cirebon City Waters, and M3 is the eastern region 


\section{HASIL DAN PEMBAHASAN}

Hasil pengujian menunjukkan logam berat mayor di $P$. viridis dari ketiga lokasi pengamatan adalah tembaga $(\mathrm{Cu})$ dan arsen (As). Kedua logam ini terakumulasi hingga melebihi $1 \mathrm{mg} / \mathrm{kg}$ berat kerang segar yang diperoleh dari perairan sisi utara dan kota Cirebon (Gambar 2). Pengolahan data multivariat diskriminan mendeteksi adanya perbedaan signifikan pada kadar logam berat di kerang yang diperoleh dari lokasi berbeda. Pola kurva kepercayaan 95\% dalam dendogram menunjukkan akumulasi logam berat di kerang dari perairan sisi utara dan kota Cirebon adalah selaras, namun berbeda secara nyata $(p<0,05)$ dengan kerang yang diperoleh di sisi timur. Selain itu, ciri logam berat dari ketiga lokasi juga terdeteksi dari pengujian diskriminan. Kerang yang diperoleh dari perairan kota memiliki kadar tembaga dan arsen yang tinggi, sementara di sisi utara memiliki merkuri yang relatif lebih tinggi. Sebaliknya, kerang hijau yang diperoleh dari perairan di sisi timur memiliki kandungan logam berat yang lebih rendah, terkecuali kadmium.

Kadar akumulasi logam berat yang terakumulasi dalam sampel masih berada di bawah ambang batas regulasi yang berlaku di Indonesia, terkecuali untuk arsen. Kadar arsen melebihi $1 \mathrm{mg} / \mathrm{kg}$ basah pada daging kerang, dengan regulasi yang saat ini berlaku di Indonesia sebesar $0,25 \mathrm{mg} / \mathrm{kg}$. Akan tetapi, Pradianti, Rahayu, dan Dewanti-Hariyadi (2019) menerangkan bahwa Codex Alimentarius Commission tidak menetapkan ambang batas untuk arsen total dan beberapa negara lainnya, seperti Australia, juga menetapkan batas hingga $2 \mathrm{mg} / \mathrm{kg}$. Berdasarkan hal ini, maka $P$. viridis asal Perairan Cirebon ini masih termasuk aman untuk dikonsumsi.

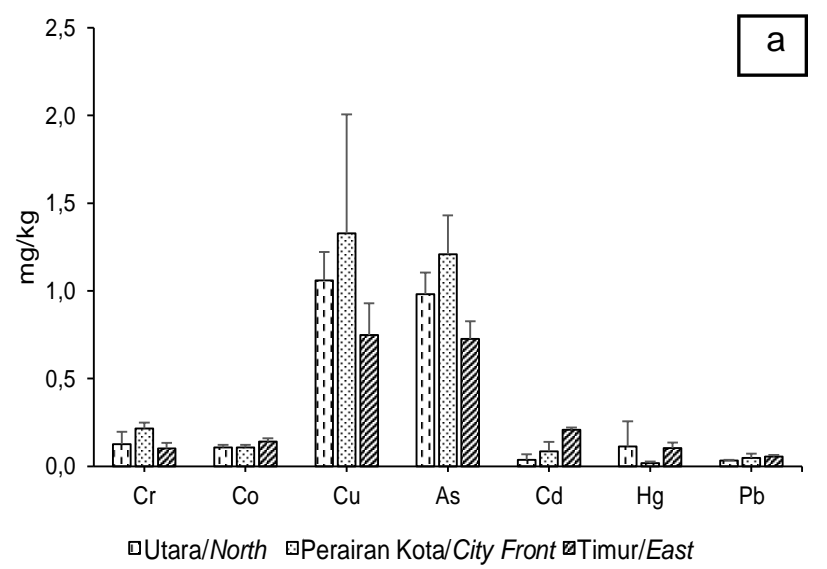

Variabilitas cemaran logam berat, yang secara umum lebih tinggi di perairan kota dan di sisi utara, dapat diduga selaras dengan tekanan antropogenik. Limpasan material antropogenik dari area industri, komersial, dan urban, telah diketahui menjadi sumber cemaran logam berat (Abadi, Zamani, Parizanganeh, Khosravi, \& Badiee, 2018). Perairan kota dan sisi utara adalah lokasi yang berbatasan langsung dengan Pelabuhan Kejawanan dan permukiman penduduk. Sebaliknya, lokasi budidaya kerang hijau di sisi timur relatif lebih jauh dari sumber antropogenik, walaupun berdekatan dengan PLTU Cirebon. Dugaan ini diperkuat oleh pengamatan visual yang menunjukkan bahwa perairan sisi utara dan perairan kota memiliki air laut dengan warna kecoklatan, sebagai indikasi adanya sedimentasi dari arah daratan. Sementara itu, sisi timur lebih jernih. Penelitian yang dilakukan oleh Zahroh, Riani, dan Anwar (2019) juga menemukan kadar logam berat di air laut pada sisi timur yang berdekatan dengan PLTU Cirebon lebih rendah jika dibandingkan dengan perairan kota dan sisi utara.

Pengujian GC-FID mendeteksi 9 jenis asam amino yang memiliki variasi komposisi berbeda antar lokasi (Gambar 3). Perbedaan yang signifikan $(p<0,05)$ terlihat pada 4 jenis asam amino, yaitu leucine, proline, phenylanaline, dan lysine. Keempat jenis ini merupakan asam amino mayor yang ditemukan dari $P$. viridis di wilayah Perairan Cirebon. Riset yang dilakukan oleh Sengor, Gun, dan Kalafatoglu (2008) juga menemukan hal yang serupa, yaitu komposisi 4 jenis asam amino tersebut ditemukan dalam persentase yang lebih tinggi dibandingkan asam amino lainnya. Faktor ekofisiologi, contohnya karakteristik abiotik seperti salinitas dan oksigen, dapat menjadi

Gambar 2. Kadar logam berat dalam kerang hijau ( $P$. viridis) yang diambil dari tiga lokasi di Perairan Cirebon (a) dan dendogram multivariat diskriminan (b)

Figure 2. Heavy metals in content green mussels ( $\underline{P}$. viridis) collected from three locations in Cirebon Waters (a) and dendogram graph of discriminant multivariate (b) 


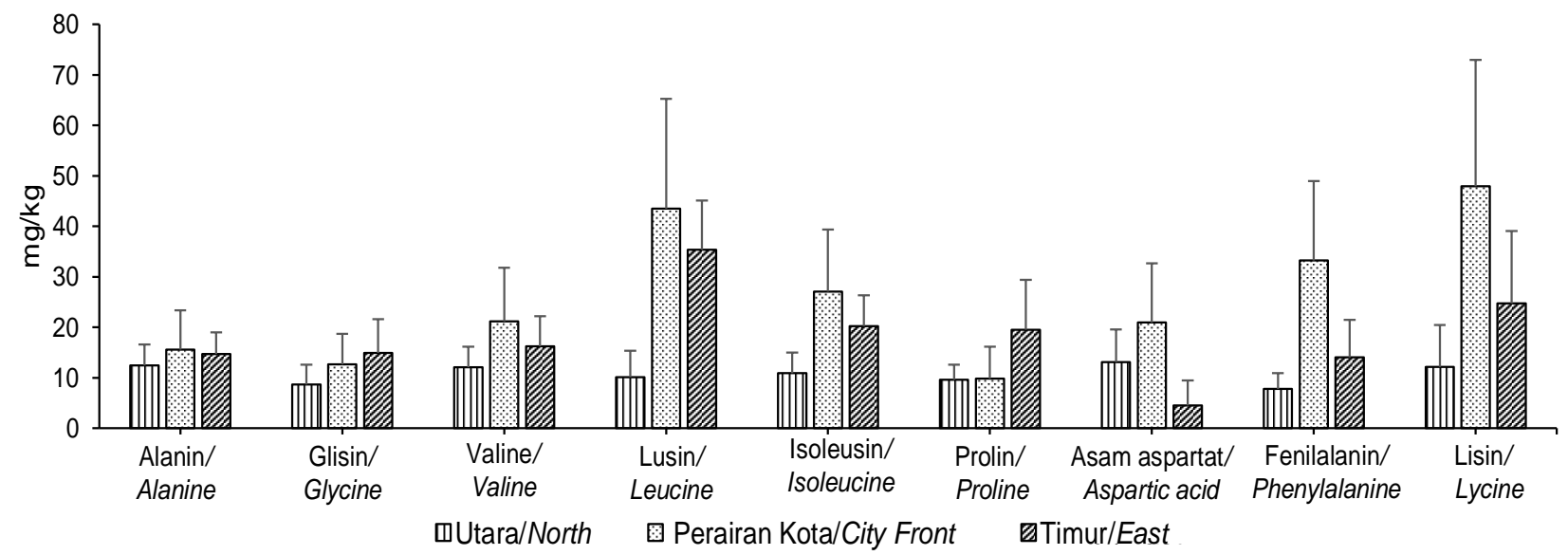

Gambar 3. Kadar asam amino dalam kerang hijau ( $P$. viridis) yang diambil dari tiga lokasi di Perairan Cirebon

Figure 3. The content of amino acids in green mussels ( $\underline{P_{.}}$viridis) collected from three locations in Cirebon Waters

faktor yang mempengaruhi komposisi asam amino dalam biota kekerangan (Kube, Sokolowski, Jansen, \& Schiedek, 2007).

Pengujian diskriminan memperlihatkan faktor lingkungan mempengaruhi komposisi asam amino di kekerangan (Gambar 4). Walaupun kerang hijau yang diperoleh di perairan kota memiliki kadar asam-asam amino yang lebih tinggi jika dibandingkan dengan kedua lokasi lainnya, namun hal ini tidak signifikan $(p>0,05)$. Pergeseran komposisi asam amino pada peningkatan jenis logam berat tertentu terdeteksi pada pengujian korespondensi. Berdasarkan letak kuadrannya di dendogram korespondensi, dapat diketahui bahwa kerang memiliki komposisi proline, glycine, alanine, dan valine yang lebih tinggi pada kenaikan akumulasi merkuri. Asam amino leucine ditemukan lebih tinggi pada akumulasi kobalt, kadmium, dan timbal. Sementara itu, asam amino lycine dan phenylalanine ditemukan lebih tinggi pada akumulasi tembaga, krom, dan arsen. Selain itu, kandungan aspartic acid terdeteksi tidak selaras dengan salah satu faktor logam berat.

Penelitian sebelumnya juga menemukan tidak adanya korelasi antara aspartic acid terhadap variasi
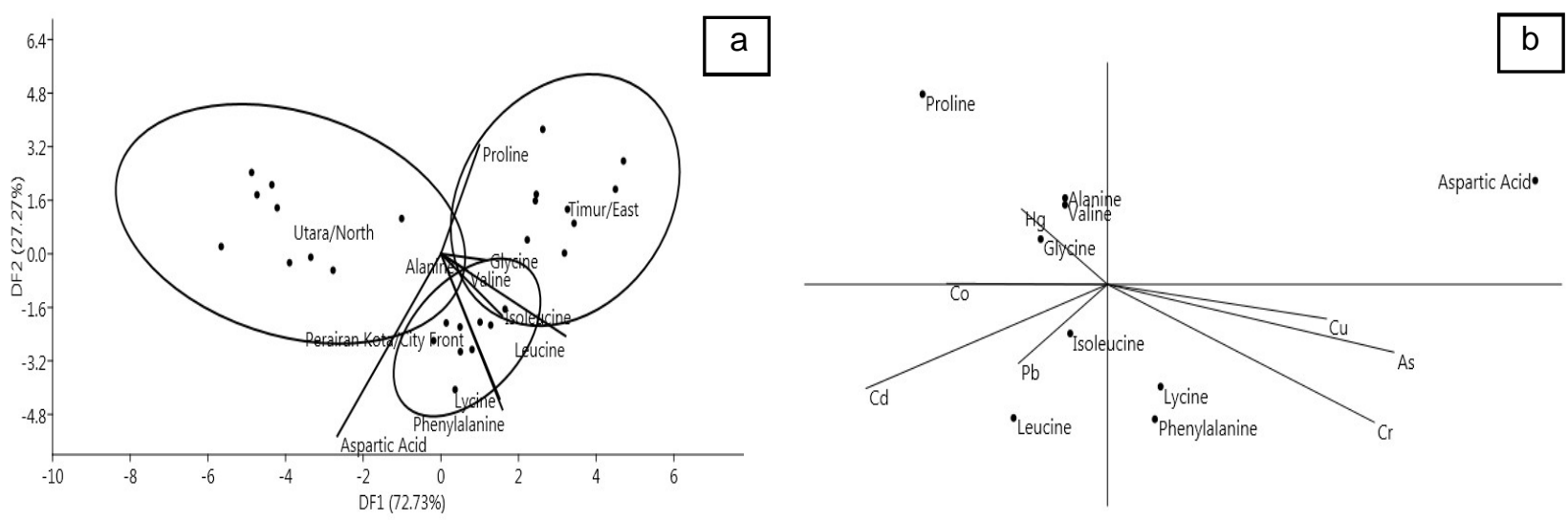

Gambar 4. Dendogram multivariat diskriminan dari komposisi asam amino kerang hijau ( $P$. viridis) budidaya dari tiga lokasi berbeda di Perairan Cirebon (a) dan multivariat korespondensi kanonikal dari akumulasi logam berat dan komposisi asam amino (b)

Figure 4. Dendogram discriminant multivariate of amino acids composisition of cultured green mussels ( $\underline{P}$. viridis) from three locations at Cirebon Waters (a) and canonical correspondence multivariate between heavy metals accumulation and amino acids composition (b) 
akumulasi logam berat. Aspartic acid merupakan alosterik modifier pyruvate kinase yang akan menyeimbangkan sel dalam kondisi kekurangan oksigen, sehingga tidak memiliki relasi terhadap peningkatan akumulasi logam berat (Storey, 1986; Blasco \& Puppo, 1999). Sementara itu, asam amino lainnya berfluktuasi sesuai dengan kadar logam berat tertentu. Hasil dari penelitian lainnya juga menemukan hal yang serupa, misalnya peningkatan konsentrasi alanine dan glycine pada kenaikan akumulasi logam merkuri serta peningkatan kadar lycine dan phenylanaline pada akumulasi logam timbal dan kadmium yang lebih tinggi (Kwon et al., 2012; Liu et al., 2011).

Hasil dari penelitian ini menunjukkan bahwa variasi komposisi asam amino dapat terjadi akibat interaksi antar akumulasi logam berat. Dendogram korespondensi memperlihatkan bahwa tingginya asam amino valine dan alanine menunjukkan akumulasi logam merkuri dalam jumlah tinggi, atau rendahnya cemaran akumulasi lainnya (karena berlawanan kuadran). Penelitian sebelumnya juga menemukan hal yang selaras. Sebagai contoh, jika terjadi kenaikan akumulasi di logam tembaga atau cadmium, maka akan terdeteksi peningkatan dari asam amino leucine, isoleucine, dan valine, namun jika keduanya terdapat dalam jumlah tinggi, maka konsentrasi ketiga jenis asam amino ini akan menurun (Wu \& Wang, 2010). Sifat tiap logam yang berbeda, dapat menyebabkan respons metabolisme yang bervariasi.

Tidak terdapat satu jenis asam amino yang dapat dijadikan penanda kimia tunggal untuk semua jenis logam berat yang terakumulasi di kekerangan. Suatu kelompok senyawa pembanding diperlukan, yang dapat ditambahkan dalam persamaan matematis dari pergeseran jenis asam amino tertentu terhadap logam berat. Senyawa pembanding yang potensial tersebut misalnya betaines. Kelompok senyawa ini memiliki fungsi sebagai senyawa antioksidan sekaligus osmoregulator (Liang, Shao, Shi, Jiang, \& Han, 2020). Pengujiannya juga mudah dan cepat, mempergunakan instrumentasi kromatografi, membuat betaines potensial untuk ditelaah agar dapat melengkapi rasio komposisi asam amino dalam penapisan awal penanda kimia pencemaran logam berat di biota kekerangan.

\section{KESIMPULAN}

Asam amino dari biota $P$. viridis dapat mengalami pergeseran komposisi, selaras dengan akumulasi logam beratnya. Kerang dapat memiliki kandungan proline, glycine, alanine, dan valine yang lebih tinggi pada kenaikan akumulasi merkuri. Asam amino leucine ditemukan lebih tinggi pada akumulasi kobalt, kadmium, dan timbal. Sementara itu, asam amino lycine dan phenylalanine ditemukan lebih tinggi pada akumulasi tembaga, krom, dan arsen. Oleh karena itu, tidak satu pun jenis asam amino tertentu yang dapat dijadikan sebagai penanda kimia umum dari akumulasi berbagai jenis logam berat. Penelitian yang lebih lanjut dapat dilakukan untuk menemukan senyawa tertentu, sebagai faktor pembanding, yang dapat melengkapi rasio komposisi asam amino sebagai penanda kimia akumulasi logam berat di biota kekerangan.

\section{UCAPAN TERIMAKASIH}

Penelitian ini didukung oleh kegiatan riset Balai Besar Riset Pengolahan Produk dan Bioteknologi Kelautan dan Perikanan, pada tahun anggaran 2019. Ucapan terima kasih diberikan untuk Sri Iswani, Anggit Prabawati, dan Rina Kurnia Lustiani, untuk bantuannya selama preparasi sampel di lapangan dan laboratorium. Selain itu, ucapan terima kasih juga diberikan untuk Stasiun Karantina Ikan, Pengendali Mutu, dan Keamanan Hasil Perikanan Cirebon, Jawa Barat, atas bantuan dan kerjasamanya selama melaksanakan penelitian.

\section{DAFTAR PUSTAKA}

Abadi, M., Zamani, A., Parizanganeh, A., Khosravi, Y., \& Badiee, H. (2018). Heavy metals and arsenic content in water along the southern Caspian coasts in Iran. Environmental Science and Pollution Research, 25(24), 23725-23735. doi: 10.1007/s11356-0182455-7

Aru, V., Sarais, G., Savorani, F., Engelsen, S.B., \& Marincola, F.C. (2016). Metabolic responses of clams, Ruditapes decussatus and Ruditapes philippinarum, to short-term exposure to lead and zinc. Marine Pollution Bulletin, 107(1), 292-299. doi: 10.1016/j.marpolbul.2016.03.054

Barokah, G. R., Dwiyitno, D., \& Nugroho, I. (2019). Kontaminasi Logam Berat (HG, PB, dan CD) dan Batas Aman Konsumsi Kerang Hijau (Perna virdis) dari Perairan Teluk Jakarta di Musim Penghujan. Jurnal Pascapanen dan Bioteknologi Kelautan dan Perikanan, 14(2), 95-106. doi : 10.15578/ jpbkp.v14i2.611

Barros, A. I., Pinheiro, F. C., Amaral, C. D., Lorençatto, R., \& Nóbrega, J. A. (2018). Aerosol dilution as a simple strategy for analysis of complex samples by ICP-MS. Talanta, 178, 805-810. doi: /10.1016/ j.talanta.2017.10.024

Blasco, J., \& Puppo, J. (1999). Effect of heavy metals $(\mathrm{Cu}, \mathrm{Cd}$ and $\mathrm{Pb})$ on aspartate and alanine aminotransferase in Ruditapes philippinarum (Mollusca: Bivalvia). Comparative Biochemistry and 
Physiology Part C: Pharmacology, Toxicology and Endocrinology, 122(2), 253-263. doi: 10.1016/S07428413(98)10116-0

Çiçek, B., \& Calýsýr, U. (2016). The investigation of complexation properties and hard-soft acid-base relationship between thiacrown ethers and metal ions. Letters in Organic Chemistry, 13(8), 572-577. doi: 10.2174/1570178613666160906105300

Falah, S., Purnomo, P. W., \& Suryanto, A. (2018). Analisis logam berat $\mathrm{Cu}$ dan $\mathrm{Pb}$ pada air dan sedimen dengan kerang hijau ( $P$. Viridis) di periaran Morosari Kebupaten Demak. Management of Aquatic Resources Journal, 7(2), 222-226.

Hammer, O., Harper, D. A. T., \& Ryan, P. D. (2001). Past: palaentological statistics software package for education and data analysis. Palaentological Electronic, 4(1), 1-9.

Jalius, J., Setiyanto, D.D., Sumantadinata, K., Riani, E., \& Ernawati, Y. (2016). Bioakumulasi Logam Berat Dan Pengaruhnya Terhadap Oogenesis Kerang Hijau (Perna viridis). Jurnal Riset Akuakultur, 3(1), 43-52. doi: 10.15578/jra.3.1.2008.43-52

Kechaou, E. S., Dumay, J., Donnay-Moreno, C., Jaouen, P., Gouygou, J. P., Bergé, J. P., \& Amar, R. B. (2009). Enzymatic hydrolysis of cuttlefish (Sepia officinalis) and sardine (Sardina pilchardus) viscera using commercial proteases: effects on lipid distribution and amino acid composition. Journal of Bioscience and Bioengineering, 107(2), 158-164. doi: 10.1016/ j.jbiosc.2008.10.018

Kim, S. H., Lim, Y., Hwang, E., \& Yim, Y. H. (2016). Development of an ID ICP-MS reference method for the determination of $\mathrm{Cd}, \mathrm{Hg}$ and $\mathrm{Pb}$ in a cosmetic powder certified reference material. Analytical Methods, 8(4), 796-804. doi: 10.1039/C5AY02040A

Kube, S., Sokolowski, A., Jansen, J. M., \& Schiedek, D. (2007). Seasonal variability of free amino acids in two marine bivalves, Macoma balthica and Mytilus spp., in relation to environmental and physiological factors. Comparative Biochemistry and Physiology Part A: Molecular \& Integrative Physiology, 147(4), 1015-1027. doi: 10.1016/j.cbpa.2007.03.012

Kwon, Y. K., Jung, Y. S., Park, J. C., Seo, J., Choi, M. S., \& Hwang, G. S. (2012). Characterizing the effect of heavy metal contamination on marine mussels using metabolomics. Marine Pollution Bulletin, 64(9), 18741879. doi: 10.1016/j.marpolbul.2012.06.012

Li, Y., Chen, C., Li, B., Sun, J., Wang, J., Gao, Y., ... Chai, Z. (2006). Elimination efficiency of different reagents for the memory effect of mercury using ICP-MS. Journal of Analytical Atomic Spectrometry, 21(1), 94-96. doi: 10.1039/b511367a

Liang, R., Shao, X., Shi, Y., Jiang, L., \& Han, G. (2020). Antioxidant defenses and metabolic responses of blue mussels (Mytilus edulis) exposed to various concentrations of erythromycin. Science of The Total Environment, 698, 134221. doi: 10.1016/ j.scitotenv.2019.134221

Liu, X., Zhang, L., You, L., Yu, J., Zhao, J., Li, L., ... Wu, H., (2011). Differential toxicological effects induced by mercury in gills from three pedigrees of Manila clam Ruditapes philippinarum by NMR-based metabolomics. Ecotoxicology, 20(1), 177-186. doi : 10.1007/s10646-010-0569-x

Murraya, M., Taufiq, N., \& Supriyantini, E. (2018). Kandungan Logam Berat Besi (Fe) Dalam Air, Sedimen Dan Kerang Hijau (Perna viridis) Di Perairan Trimulyo, Semarang. Journal of Marine Research, 7(2), 133-140. doi: 10.14710/jmr.v7i2.25902

Nurhayati, D., \& Putri, D. A. (2019). Bioakumulasi Logam Berat pada Kerang Hijau (Perna viridis) di Perairan Cirebon Beradasarkan Musim yang Berbeda. Akuatika Indonesia, 4(1), 6-10. doi: 10.24198/ jaki.v4i1.23484

Pradianti, O. S., Rahayu, W. P., \& Dewanti-Hariyadi, R. (2019). Kajian Kesesuaian Standar Cemaran Kimia (Logam Berat dan PAH) pada Produk Perikanan di Indonesia dengan Standar Negara Lain dan Codex. Jurnal Pascapanen dan Bioteknologi Kelautan dan Perikanan, 14(1), 45-62. doi: 10.15578/ jpbkp.v14i1.560

Sengor, G. F. Ü., Gun, H., \& Kalafatoglu, H. (2008). Determination of the amino acid and chemical composition of canned smoked mussels (Mytilus galloprovincialis, L.). Turkish Journal of Veterinary and Animal Sciences, 32(1), 1-5.

Sindern, S., Tremöhlen, M., Dsikowitzky, L., Gronen, L., Schwarzbauer, J., Siregar, T. H., ... Irianto, H.E. (2016). Heavy metals in river and coast sediments of the Jakarta Bay region (Indonesia)-Geogenic versus anthropogenic sources. Marine Pollution Bulletin, 110(2), 624-633. doi: 10.1016/j.marpolbul.2016.06.003

Siregar, T. H., Priyanto, N., Putri, A. K., Rachmawati, N., Triwibowo, R., Dsikowitzky, L., \& Schwarzbauer, J. (2016). Spatial distribution and seasonal variation of the trace hazardous element contamination in Jakarta Bay, Indonesia. Marine Pollution Bulletin, 110(2), 634646. doi: 10.1016/j.marpolbul.2016.05.008

Storey, K. B. (1986). Aspartate activation of pyruvate kinase in anoxia tolerant molluscs. Comparative Biochemistry and Physiology Part B: Comparative Biochemistry, 83(4), 807-812. doi: 10.1016/03050491(86)90151-3

Wu, H., \& Wang, W. X. (2010). NMR-based metabolomic studies on the toxicological effects of cadmium and copper on green mussels Perna viridis. Aquatic Toxicology, 100(4), 339-345. doi: 10.1016/ j.aquatox.2010.08.005

Wu, H., Xu, L., Yu, D., \& Ji, C. (2017). Differential metabolic responses in three life stages of mussels Mytilus galloprovincialis exposed to cadmium. Ecotoxicology, 26(1), 74-80. doi: 10.1007/s10646-016-1741-8

Wu, J., Zhou, J., Zhang, S., Alsaedi, A., Hayat, T., Li, J., \& Song, Y. (2019). Efficient removal of metal contaminants by EDTA modified MOF from aqueous solutions. Journal of Colloid and Interface science, 555, 403-412. doi: 10.1016/j.jcis.2019.07.108

Yu, D., Ji, C., Zhao, J., \& Wu, H. (2016). Proteomic and metabolomic analysis on the toxicological effects of As (III) and As (V) in juvenile mussel Mytilus 
JPB Kelautan dan Perikanan Vol. 15 No. 2 Tahun 2020:107-114

galloprovincialis. Chemosphere, 150, 194-201. doi: 10.1016/j.chemosphere.2016.01.113

Zahroh, A., Riani, E., \& Anwar, S. (2019). Analisis kualitas perairan Kabupaten Cirebon - Provinsi Jawa Barat. Jurnal Pengelolaan Sumberdaya Alam dan Lingkungan, 9(1), 86-91. doi: 10.29244/jpsl.9.1.86-91
Zhang, L., Liu, X., You, L., Zhou, D., Wu, H., Li, L., ... Yu, J (2011). Metabolic responses in gills of Manila clam Ruditapes philippinarum exposed to copper using NMR-based metabolomics. Marine Environmental Research, 72(1-2), 33-39. doi: 10.1016/ j.marenvres.2011.04.002 